\title{
Antimicrobial activity and phytochemical analysis of Calotropis gigantea root, latex extracts.
}

\author{
${ }^{1,}$ Pramila kori* and ${ }^{2,}$ Prerana alawa \\ ${ }^{1,2,}$ Department of chemistry, \\ Govt. Holkar Science College, Indore (M.P.), India
}

\begin{abstract}
The root and latex of Calotropis gigantea were screened for its antimicrobial and phytochemical activities. The solvents used for the roots and latex extraction were $n$-hexane, benzene, acetone, ethanol, aqueous. The extract was tested against infectious disease causing bacterial such as Escherichia coli, Pseudomonas aeruginosa, Staphylococcus aureus using the well diffusion method. The aqueous, ethanolic and acetone extract of root of calotropis gigantea inhibition against all the test microbe ranging from $10 \mathrm{~mm}$ to 16 mm diameter inhibitory zone. The aqueous and ethanolic extract of latex of calotropis gigantea inhibition against all the test microbe ranging from $10 \mathrm{~mm}$ to $18 \mathrm{~mm}$ diameter inhibitory zone. In present study, bacterial extract showed a varying zone of inhibition of the growth of tested organism than n-hexane, benzene, ethanol, and aqueous. Phytochemical properties of root and latex of Calotropis gigantea obtain from $n$ - hexane, benzene, acetone, ethanol and aqueous extracts were investigated. The results confirmed that presence of antibacterial activity and phytochemical in the shade dried extract of Calotropis gigantea against the human pathogenic organisms.
\end{abstract}

KEYWORD: Calotropis gigantea crude extract, phytochemicals, antimicrobial activity

\section{INTRODUCTION}

A medicinal plant is any plant which, in one or more of it contains substance that can be used for therapeutic purpose or which is a precursor for synthesis of useful drugs. The plants posses therapeutic properties or exert Beneficial Pharmacological effects on the animal body are generally designated as "Medicinal Plant". In current scenario of medical and pharmaceutical advancement, microbes involve in the change of their metabolism and genetic structure to acquire resistant against the drugs used in the treatment of common infection disease. ${ }^{(1),(2)}$ The continued emergence or persistence of drug resistant organisms and the increasing evolutionary adaptation by pathogenic organisms to commonly used antimicrobials have reduced the efficacy of antimicrobial agent currently in use. ${ }^{(3)}$ Plant have the capacity to produce a large number of organic chemicals called as phytochemicals. The accumulation of phytochemicals in the plant cell cultures had been studied for than thirty years and the generated knowledge had helped in realization of using cell culture for the production of desired phytochemicals. ${ }^{(4)}$

Calotropis belong to Asclepidaceae family. It is also known as Akada, Aak, Mandar, Aakh etc. It has two species procera and gigantea .here we study about Calotropis Gigantea. ${ }^{(5)}$ The roots and leaves of calotropis gigantea are used traditionally for treatment of abdominal, tumours boils, skin diseases, wound, insect bites. A literature review showed that Calotropis Gigantea contained cardenolide, glucosides, a non protein, amino acid, flavonoids and steroids. Calotropis gigantea in small dose are also useful in the treatment of cold, cough, asthma inflammatory diseases and loss of digestive and analgesic property of Calotropis Gigantea $^{(6),(7)}$ Milky sap is used in the treatment of boils, scabies, burns, bruises, cuts, sores, stopping blood, and wound healing; Leaves are used in chest congestion and cardiovascular conditions. The roots and barks of C. gigantea are in use for paralysis, fits, epilepsy, and convulsions in children. Shoot, leaf, roots flowers and latex extracts are reported to have antibacterial and antifungal properties by researchers. ${ }^{(8)}$ This study amied to find out the phytochemical content and its antimicrobial activity of root and latex extracts of Calotropis gigantea.

\section{MATERIALS AND METHODS COLLECTION OF PLANT MATERIAL:}

Collection of plant material the leaves and fruits of Calotropis gigantea also known as crown flower; was done from the areas around Bhabra of District Alirajpur, Madhya Pradesh. The identification of the whole plant and its parts were done by Dr. Kishor Panwar department of Botany, Holkar Science College, Indore, Madhya Pradesh. 


\section{EXTRACTION OF PLANT}

Latex is a complex emulsion of polymer micro particles in an aqueous medium. The extractions from latex are quit tricky in context with preparation of latex for the extraction purpose. For this, the latex was collected from the injured tissues of plant $C$. gigantea, by making an incision on the stem part. The obtained latex was then centrifuged at 5000 RPM in the laboratory and the supernatant aqueous phase was decanted and the sticky rubber like matter is pulled out of centrifuge tube and properly dried for 2-3 days. The matter is then processed into smaller particles in mortar pestle. The rest process for extraction is similar to those the extraction for leaves, roots and fruits. 10 grams of dried latex was subjected to Soxhlet extraction with $200 \mathrm{ml}$ of solvents starting from pure distilled water, followed by extraction with other solvents Ethanol, Acetone n-Hexane and Benzene in separate ways.

The twigs of the roots of Calotropis gigantea were washed and allowed to dry in shade for a week and then grounded into fine powder in mixer grinder. Similar as the extraction for leaves, 10 grams of dried powder of roots was subjected to Soxhlet extraction with $200 \mathrm{ml}$ of solvents starting from $\mathrm{n}$-hexane, followed by extraction with other solvents Benzene and Acetone Ethanol and pure distilled water in separate ways.

Soxhlet process was allowed to carry out till the complete exhaustion of sample material use for extraction with the maintenance of temperature below the boiling points of the solvents used. The extract so obtained is subjected to evaporation of solvent to get the extract in crystalline/slurry form which were suitably diluted and used for preliminary phytochemical analysis and studies of their antimicrobial activity.

\section{PHYTOCHEMICAL ANALYSIS OF THE EXTRACT:}

A small portion of the dry extracts were subjected to the phytochemical test using Harbourne's (1983) methods to test for alkaloids, tannins, terpenoids, saponins, flavonoids and glycosides.

Test for alkaloids: About $0.2 \mathrm{~g}$ extract warmed with $2 \% \mathrm{H}_{2} \mathrm{SO}_{4}$ for two minutes, filtered and few drops of Dragendorff's reagent added orange red precipitate indicates the presence of alkaloids. And or filtrates were treated with Wagner's reagent (Iodine in Potassium Iodide). Formation of brown/reddish precipitate indicates the presence of alkaloids.

Test for glycosides: The extracts hydrolyzed with $\mathrm{HCl}$ solutions and neutralized with $\mathrm{NaOH}$ solutions. A few drops of Fehling solution A and B were added. Red precipitate indicates the presence of glycoside. Another test use was Benedict's test, in which the filtrates were treated with Benedict's reagent and heated gently. Orange red precipitate indicates the presence of reducing sugars.

Test for tannins: Small quantity of extracts mixed with water, heated, filtered and ferric chloride added. A dark green solution indicates the presence of tannins.

Test for saponins: About $0.2 \mathrm{~g}$ of the extracts shaken with $5 \mathrm{ml}$ of distilled water and then heated to boil frothing (appearance of creamy mix of small bubbles) shows the presence of saponins.

Test for flavonoids: Extract of about $0.2 \mathrm{~g}$ of the extracts shaken with $5 \mathrm{ml}$ of distilled water and then a few drops of $10 \%$ lead acetate solution is added. A yellow or dirty white precipitate shows the presence of flavonoids. ${ }^{(9)}$

\section{CULTURE MEDIA AND INOCULUM PREPARATION:}

Nutrient agar broth cultures of the pure culture isolates of Staphylococcus aureus, E. coli and Pseudomonas aeruginosa were prepared by transferring a loop of culture into sterile nutrient broth and incubated at $37^{\circ} \mathrm{C}$ for 48 hours. A loop full was taken from these broths and seeded onto sterile nutrient agar plates through sterile cotton swab to develop diffused heavy lawn culture.

\section{ANTIMICROBIAL ACTIVITY:}

The well diffusion method was used to determine the antibacterial activity of the extracts prepared from the Calotropis gigantea roots and latex using standard procedure. In this method, first the test bacteria broth of bacteria are used to inoculate on the nutrient agar plates with the help of sterile cotton swabs to develop the lawn culture. Then to these plates $6 \mathrm{~mm}$ diameter well are punched in agar plates pre-inoculated with test microorganisms Undiluted over night broth cultures should never be used as an inoculam routine direct application of suitably diluted extracts are poured into the well. The plates were incubated at $37^{\circ} \mathrm{C}$ for $24 \mathrm{hr}$. and then examined for clear zones of inhibition. Sterile water was used as control. ${ }^{(10)}$ 
RESULTS AND DISCUSSION:

\section{PHYTOCHEMICAL ANALYSIS OF BIOACTIVE COMPOUND IN DIFFERENT SOLVENT EXTRACTS OF CALOTROPIS GIGANTEA}

The plant root extracts in different solvent were screened for the presence of various bioactive phytochemical compounds. The aqueous roots extracts of Calotropis gigantea were found highly rich in alkaloids and glycosides, although terpenoids are totally absent in them. Saponins are the only which are present in all the root extract under evaluation. The n-hexane extracts were poor in their phytochemical contains.

The plant latex extract in different solvent were screened for the presence of various bioactive phytochemical compounds the acetone and ethanolic latex extract of Calotropis gigantea were found rich in alkaloids, glycosides, tannins and saponins. Saponins are the only which are present in all the letax extract under evaluation. The n-hexane and benzene extracts were poor in their phytochemical contains. This were documented in Table $1 \& 2$.

Table 1: Phytochemical Analysis of Calotropis gigantea extracts from Root.

\begin{tabular}{|c|l|c|c|c|c|c|}
\hline \multirow{2}{*}{ S.N } & \multirow{2}{*}{ Constituents } & \multicolumn{5}{|c|}{ Soxhlet Extractions of Root Samples to C. gigantea } \\
\cline { 3 - 7 } & & $\begin{array}{c}\text { n-Hexane } \\
\text { Extract }\end{array}$ & $\begin{array}{c}\text { Benzene } \\
\text { Extract }\end{array}$ & $\begin{array}{c}\text { Acetone } \\
\text { Extract }\end{array}$ & Ethanolic Extract & $\begin{array}{c}\text { Aqueous } \\
\text { Extract }\end{array}$ \\
\hline $\mathbf{1}$ & Alkaloids & - & +2 & +3 & +4 & +5 \\
\hline $\mathbf{2}$ & Glycosides & - & + & +5 & - & +5 \\
\hline $\mathbf{3}$ & Tannins & - & - & + & +2 & +2 \\
\hline $\mathbf{4}$ & Saponins, & + & +2 & +5 & +5 & +3 \\
\hline $\mathbf{5}$ & Flavonoids & - & + & - & +3 & +3 \\
\hline $\mathbf{6}$ & Terpenoids & - & - & - & - & - \\
\hline
\end{tabular}

$[(+)$ means present, $(+2$ or +3$)$ means Prominent, $(+5)$ means highly prominent and $(-)$ means absent $]$

Table 2 Phytochemical Analysis of Calotropis gigantea extracts from Latex.

\begin{tabular}{|c|l|c|c|c|c|c|}
\hline \multirow{2}{*}{ S.N } & \multirow{2}{*}{ Constituents } & \multicolumn{5}{|c|}{ Soxhlet Extractions of Latex Samples to C. gigantea } \\
\cline { 3 - 7 } & $\begin{array}{c}\text { n-Hexane } \\
\text { Extract }\end{array}$ & $\begin{array}{c}\text { Benzene } \\
\text { Extract }\end{array}$ & $\begin{array}{c}\text { Acetone } \\
\text { Extract }\end{array}$ & Ethanolic Extract & $\begin{array}{c}\text { Aqueous } \\
\text { Extract }\end{array}$ \\
\hline $\mathbf{1}$ & Alkaloids & - & - & +2 & + & - \\
\hline $\mathbf{2}$ & Glycosides & - & - & +3 & + & - \\
\hline $\mathbf{3}$ & Tannins & - & - & +4 & +3 & - \\
\hline $\mathbf{4}$ & Saponins, & + & +3 & +5 & +2 & +3 \\
\hline $\mathbf{5}$ & Flavonoids & - & - & +5 & +3 & - \\
\hline $\mathbf{6}$ & Terpenoids & - & - & +3 & +2 & - \\
\hline
\end{tabular}

$[(+)$ means present, $(+2$ or +3$)$ means Prominent, $(+5)$ means highly prominent and (-) means absent $]$

\section{ANTIMICROBIAL ACTIVITY OF DIFFERENT ORGANIC SOLVENT EXTRACTS OF CALOTROPIS GIGANTEA}

Antimicrobial activity of different solvent extract of calotropis gigantea is shown in table that the aqueous, ethanolic and acetonic extracts of Root of $C$. gigantea impart sufficient inhibitory actions against the test microbe ranging from $10 \mathrm{~mm}$ to $16 \mathrm{~mm}$ diameter inhibitory zones. And out of the hexane and benzene extracts only limited inhibition was observe in benzene extract against the E. coli only.

The ethanolic and aqueous extracts of latex of $C$. gigantea impart sufficient inhibitory actions against the test microbe ranging from $10 \mathrm{~mm}$ to $18 \mathrm{~mm}$ diameter inhibitory zones. The aqueous extract of latex has maximum zone of inhibition against the Staphylococcus aureus the common Gram positive pathogenic microorganism and this is the maximum inhibitory potential out of the all extracts viz. root and latex. But the acetonic, hexane and benzene extracts of latex has no inhibition against any organism. The result of antibacterial activity are shown in table $3 \& 4$ and figure $1 \& 2$ 
Antimicrobial activity and phytochemical analysis of Calotropis gigantea root, latex extracts.

Table 3: Result of the antimicrobial activity of root extracts of Calotropis gigantea.

\begin{tabular}{|l|l|l|l|c|c|c|}
\hline \multirow{2}{*}{ S.N } & \multirow{2}{*}{ Test microbes } & \multicolumn{4}{|l|}{ Zone of Inhibition due to C. gigantean (L.) Br. root extracts 1 mg/ml (in mm) } \\
\cline { 3 - 7 } & $\begin{array}{l}\text { n-Hexane } \\
\text { extract }\end{array}$ & $\begin{array}{l}\text { Benzene } \\
\text { Extract }\end{array}$ & $\begin{array}{l}\text { Acetonic } \\
\text { Extract }\end{array}$ & $\begin{array}{l}\text { Ethanolic } \\
\text { Extract }\end{array}$ & $\begin{array}{l}\text { Aqueous } \\
\text { extract }\end{array}$ \\
\hline $\mathbf{1 .}$ & Staphylococcus aureus & Nil & Nil & 16 & 13 & 14 \\
\hline $\mathbf{2 .}$ & Escherichia coli & Nil & 10 & 14 & 12 & 11 \\
\hline $\mathbf{3 .}$ & $\begin{array}{l}\text { Pseudomonas } \\
\text { aeruginosa. }\end{array}$ & Nil & Nil & 10 & 13 & 12 \\
\hline
\end{tabular}

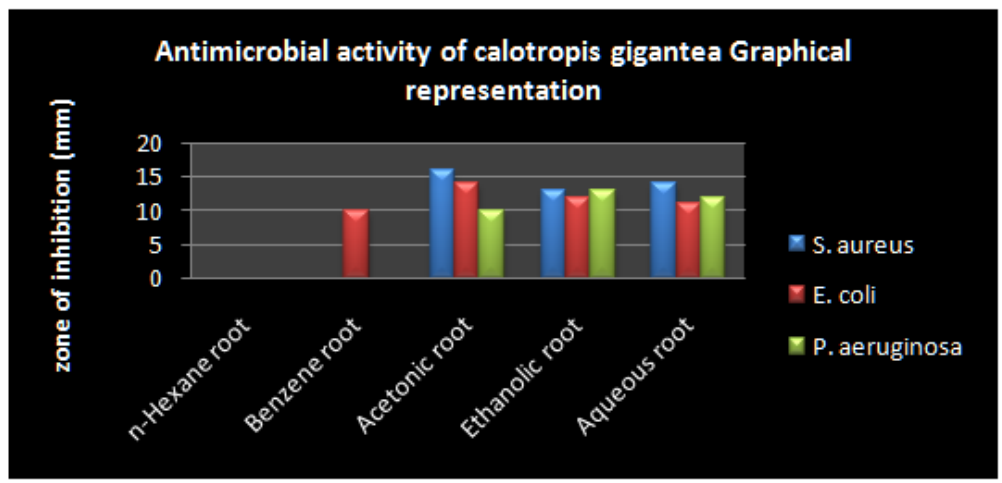

Figure 1: Screening for Antimicrobial Activity of Calotropis gigantea root of extracts to three Test species.

Table 4: Results of the antimicrobial activity of Latex extracts of Calotropis gigantea.

\begin{tabular}{|c|l|c|c|c|c|c|}
\hline \multirow{2}{*}{ S.N } & \multirow{2}{*}{ Test microbes } & \multicolumn{3}{|c|}{ Zone of Inhibition due to C. gigantean (L.) Br. latex extracts 1mg/ml (in mm) } \\
\cline { 3 - 7 } & $\begin{array}{c}\text { n-Hexane } \\
\text { extract }\end{array}$ & $\begin{array}{c}\text { Benzene } \\
\text { Extract }\end{array}$ & $\begin{array}{c}\text { Acetonic } \\
\text { Extract }\end{array}$ & $\begin{array}{c}\text { Ethanolic } \\
\text { Extract }\end{array}$ & $\begin{array}{c}\text { Aqueous } \\
\text { extract }\end{array}$ \\
\hline 1. & Staphylococcus aureus & Nil & nil & Nil & 15 & 18 \\
\hline $\mathbf{2 .}$ & Escherichia coli & Nil & nil & Nil & 14 & 16 \\
\hline 3. & $\begin{array}{l}\text { Pseudomonas } \\
\text { aeruginosa. }\end{array}$ & Nil & nil & Nil & 10 & 14 \\
\hline
\end{tabular}

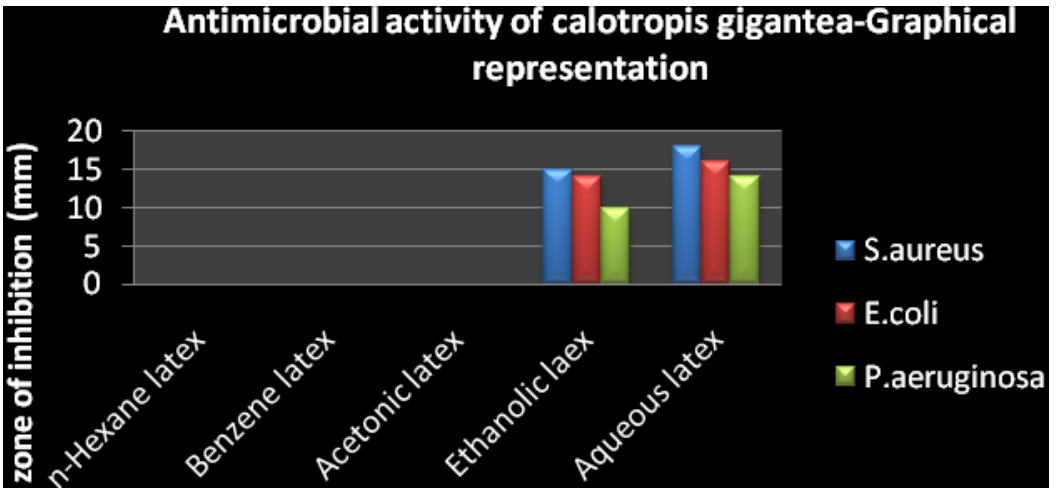

Figure 2: Graphical representation of Antimicrobial Activity of Calotropis gigantea latex of extracts to three Test species.

Antibactrial activity of different solvent extacts of $C$. gigantea showed vayring degrees of antibacterial activity against all microorganisms tested. ${ }^{(11)}$ There are many reports of plants in the family Asclepiadaceae possessing antimicrobial activity. ${ }^{(12,13)}$ From this study it can be said that, actone ethanol and aqueous shade dried root extract and ethanol and aqueous shade dried latex extract of $C$. gigantea showed wide range of antibacterial activity can be used and administered in the ethano medical practice. ${ }^{(14,15)}$ The results obtained from our study showed an effective inhibition against the test organism which justify the traditional use of the plant for infection diseases. 


\section{CONCLUSION:}

The encouraging results indicate that the aqueous, ethanolic, acetonic, n-hexane and benzene extracts of various parts of Calotropis gigantea might be exploited as a natural drug for the treatment of several infectious diseases caused by these organisms and could be useful in understanding the relations between traditional cures and current medications. Our results showed that in present work that extracts obtained different parts of the plant Calotropis gigantea using various solvents are rich sources of potent phytochemicals especially the roots and latex extract and has inhibitory effects on the experimental microbes. From previous studies and the current work it is clear that the plant is rich source of alkaloids, glycoside, tannins, saponins, flavonoids, terpenoids etc. These bioactive complex phytochemicals can be used for the development of potent drugs, medicines or antimicrobial agents that can be used for various purposes for human welfare upon further extensive \& systematic studies.

\section{REFERENCES}

[1]. Balandrin MF, Klocke JA, Wurtele ES, Bollinger WH, Natural Pant Chemicals, Sci. 1985, 1154-1160.

[2]. Rahman, Md. S., Moly, N. N. And Hossen, Md. Review on a potential herb Calotropis gigantea J. Int. J. Of Phrmaceutical Sciences and Res., 2013. 4(2):745-753.

[3]. Fransworth NR, Morris RN. Higher plants. The sleeping giants of drug development. Am. J. Pharm, 1976, 147(2): 46-56.

[4]. Castello M, Phatak A, Chandra N and Sharon M, Antimicribial activity of crude extract from plant parts and corresponding calli of FBixa orellana L Indian J. Exp. Biol. 2002, 40, 1378-1381.

[5]. Lindley, J., Flora Medica. Ajay Book Servies, 1985, New Dehli.

[6]. Kartikar, K. R. And B.D. Basu, Indian Medicinal Plants,Edn 2 ${ }^{\text {nd }}$, Allahabad, India. 1994, Vol. 3, 1606-1609.

[7]. Chitme, H.R., R. Chandra and S. Kaushik, Evalution of antipyretic activity of calotropis gigantea (Asclepiadaceae) in experimental animals. Phytothrapy Research, 2005, 19 (5):454-6.

[8]. Suresh Babu AR and Karki SS, Wound Healing Activity of Calotropis gigantea leaves in Albino Wistar Rats. International Journal of Pharmacy. 2012,. 2(1): 195-199

[9]. Trease, G. E. and Evans, W. C.1989, A textbook of Pharmacognosy. Bacilliere tinal Ltd., London, 13 edition.

[10]. Satish, S., D.C. Moohana, M.P. Ranhavendra and K.A. Raveesha, ; Antibacterial activity of some pathogenic of Aspergillus sp. J. of Agriclture Technology, 2007, 3: 109-119.

[11]. Subhramaninan S.P. and Saratha V. Evalution of Antimicrobial Activity of Calotropis gigantea Latex Extract on Selected Pathogenic Bacteria. Journal of Pharmacy Research, 2010; Vol3,No,3.

[12]. Sukanya S. L. Sudisha J. Hariparasad P., Niranjana S. R. Prakash H. S. and Fathima S. K. Antimicrobial activity of leaf extracts of Indian medicinal plants against clinical and phytopathogenic bacteria. African Journal of Biotechnology. 2009; 8(23): 66776682.

[13]. Loganathan Karthik. and Kokati venkat B., haskard Rao., Antimicrobial activity of latex of calotropis gigantea Against pathogenic microorganisms an in vitro study. I. J. of Pharm. Sci. Rev. Res. 2010, Vol,3; pp.155 -158

[14]. Murti PBR. and Seshadri TR., Chemical composition of Calotropis gigantea: Part V. Further Examination of the Latex and Root Bark, Proc. Ind. Acad. Sci, 1945, 21: 143 - 147.

[15]. Kalpesh B. ishnava., Antibacterial and phyto-chemical studies on calotropis gigantea (L.) R.Br., Latex against selected cariogenic bacteria. Saudi, J. of Bio. Sci. 2012, vol, 19, 87-91. 